\title{
TÜKÖR ÁLTAL NEM ELHOMÁLYOSÍTVA (A POSZTMODERN, A PARADIGMÁK, A MAIN STREAM ÉS A CSÁBÍTÁS ÖRDÖGE A REGIONÁLIS TUDOMÁNYBAN)
}

\author{
(Not Being Blured by a Mirror \\ The Post-modern, the Paradigm, the Main Stream and the Evil \\ of Temptation in the Science of Regionalism)
}

RECHNITZER JÁNOS

Kulcsszavak:

regionális tudomány kutatás irányzatok

A tanulmány a regionális tudomány magyarországi helyzetét tekinti át. A SWOT-elemzésre építve gondolja végig ennek az ủj, egyre dinamikusabban fejlödö társadalomtudománynak az erösségeit, gyengeségeit és lehetöségeit, veszélyeit. A szerzó megállapítja, hogy Magyarországon intézményesült a regionális tudomány, müködésênek minden feltétele és követelménye kiépült. Társadalmi befogadottsága és hatása e gyre jelentösebb, növekszik az érdeklódés az eredmények és az alkalmazás iránt. Ugyanakkor a nagyszámú elemzés még csak feldolgozását adta a magyar átmenet regionális folyamatainak és intézményeinek, ezekböl átfogó elméleti megállapításokat nem alkotott meg. Mérsékelt a tudományterület alapozó elméleti irodalma, amik a hazai kutatásokra építenek, de fokozatos elmozdulás figyelhetö meg. Évekig csak részképzésben oktatták a regionális tudomány egyes alkotóit, de remény van arra, hogy a kétszintü képzésben mester fokon elkezdödjön a képzés. A tudontányterület lehetöségei bövïlttek, hiszen megteremtôdtek a Kárpát-medencében, illetve Közép-Európában a tudományos együttmüködés feltételei. Az érdeklödés a jövöben fokozódik a regionális elemzések iránt. A veszélyekkel is számolni kell, hiszen a kutatások kitettek a politikának, gyakran dilemmát okoz a tanácsadás és a kutatás elválasztása, de emlitést érdemel, hogy egyre több különbözö képességü versenytárs jelenik meg a társadalomelemzési és fejlesztési piacon. A regionális tudomány Magyarországon erös poziciókat szerzett, a jövöben a legfontosabb, hogy azokat nemzetközi vonatkozásban is tesztelje, eredményeit bemutassa.

Idóközönként, ahogy az életben, úgy a szakmáknak is tükörbe kell nézni. Végig kell gondolni, hogy mi történt eddig, mi legyen holnap, s azután. A tukör mi, a szakmai közösség vagyunk, azok, akik a regionális tudományt mủvelik. Legyenek közöttünk olyanok, kik ebből élnek, s legyen kik munkájuknak, netalántán hivatásuknak tekintik a regionális tudományt. Mikor jön el a nagy szembenézés ideje? Általában évfordulókon, nos ennek alkalma megvolt az elmúlt év végén, hiszen lejárt az MTA Regionális Tudományos Bizottságának 6. ciklusa, így elkészült a 2003-2005. évi müködés beszámolója ${ }^{1}$. Az önértékelés ideje eljöhet csak úgy is, mert megérlelödött valakikben valami ${ }^{2}$, esetleg időközönként fel kell rázni a társaságot, de az is előfordul, hogy a szakma müvelöi krónikus identitásproblémákkal küzdenek, s ezt valahogy csillapítani szïkséges.

A regionális tudomány mủvelőinél ezen utóbbi pszichikai állapot gyakran előfordul. Sokan vannak közülünk, akik a szakmai identitásukat keresik, a tudományterület 
Rechnitzer János : Tükör által nem elhomályositva (A posztmodern, a paradigmák, a main stream és a csábitás ördöge a regionális tudományban.) Tér és Társadalom 19. évf. 2005/3-4. 1-12. p.

belső értékekeit gondolják át, a külső kedvezö vagy kedvezötlen megítéléseiket mérlegelik, s ezek alapján kiutakat, új megközelítéseket keresnek. Nemes Nagy József legutóbbi ezzel foglalkozó tanulmányában (Nemes Nagy 2003) a belső, a tudományterület lényegét - szubsztanciáját - feszegetö gondolatokat vetett fel, s állít fel egy rendszert, s egyben értéket, megítéléseket fogalmaz meg. A következökben közreadott - talán vitát serkentő, bár ez a hazai tudományosságban már nem divat - töprengéseinket részben ezen tanulmány újraolvasása indította el, részben pedig több vita, konferencia, ahol fiatalabb és idősebb regionalisták előadásait hallgattuk a kutatásaikról, a tudományterület lehetséges jövőbeli kutatási irányairól ${ }^{3}$.

Míg a fentiek indították meg a regionális tudomány helyzetével és jövöbeli megújítási irányaival kapesolatos gondolatainkat, addig azok formába rẹndezését már Izsák Éva inspirálta, aki egy konferencián a tudományterület első SWOT-elemzését állította össze ${ }^{4}$. A tervezésben alkalmazott közkedvelt eljárás merész alkalmazása egy tudományterületre, kiváló keretet biztosít az erősségeink, a gyengeségeink, a veszélyeink és lehetőségeink rendszerzésére, s egyben a hazai regionális tudomány jövöbeli fejlödési irányainak a kijelölésére. Átdolgoztuk, kiegészitettük Izsák Éva gondolatébresztó értékelési eljárását, $\mathrm{s}$ további elemzésünkben annak nem mindegyik, hanem inkább általunk lényegesnek tartott elemeit fejtjük ki részletesebben (1. táblázat).

\section{TÁBLÁZAT}

A regionális tudomány sajátosságainak értékelése

(Evaluation of Specialities of Regional Science)

\begin{tabular}{|c|c|c|c|}
\hline ERÖSSÉG & GYENGESÉG & VESZÉLY & LEHETŐSÉG \\
\hline $\begin{array}{l}\text { Nyitottság, sokszínủ- } \\
\text { ség, komplexitás! }\end{array}$ & $\begin{array}{l}\text { Enciklopédikus mü- } \\
\text { vek hiánya, eredmé- } \\
\text { nyek elméleti feldol- } \\
\text { gozása elmaradt! }\end{array}$ & $\begin{array}{l}\text { Tudomány helyett } \\
\text { politika-alakítás! }\end{array}$ & $\begin{array}{l}\text { Transzdiszciplináris } \\
\text { jelleg erősítése, hatá- } \\
\text { rozottabb érvényesí- } \\
\text { tése! }\end{array}$ \\
\hline $\begin{array}{l}\text { Változó erősségủ } \\
\text { nemzetközi tudomá- } \\
\text { nyos bázis! }\end{array}$ & $\begin{array}{l}\text { Regionális kutatások } \\
\text { módszertana egysíkú, } \\
\text { leíró! }\end{array}$ & $\begin{array}{l}\text { Befelé fordulás, nem- } \\
\text { zetközi megmérette- } \\
\text { tés elmaradása! }\end{array}$ & $\begin{array}{l}\text { Kárpát-medencei } \\
\text { hálózat, kutatási } \\
\text { centrum! }\end{array}$ \\
\hline $\begin{array}{l}\text { Intézményesủlés; } \\
\text { MTA kutatóintézet, } \\
\text { publikációs fórumok, } \\
\text { felsóoktatás! }\end{array}$ & $\begin{array}{l}\text { Önálló egyetemi szak } \\
\text { hiánya, részképzés- } \\
\text { ben való megjelenés! }\end{array}$ & $\begin{array}{l}\text { Mennyiség és minő- } \\
\text { ség viszonya, } \\
\text { expressz kutatások! }\end{array}$ & $\begin{array}{l}\text { Kutatási források } \\
\text { egyre bővülö köre } \\
\text { (EU), nemzetközi } \\
\text { együttmüködések! }\end{array}$ \\
\hline $\begin{array}{l}\text { Nơvekvő alkalmazói } \\
\text { és felhasználói kör, } \\
\text { gyakorlati igények! }\end{array}$ & $\begin{array}{l}\text { Eredmények csak } \\
\text { részben épülnek be a } \\
\text { döntésekbe, hiányos } \\
\text { visszajelzések! }\end{array}$ & $\begin{array}{l}\text { Tanácsadás, vagy } \\
\text { kutatás dilemmája! }\end{array}$ & $\begin{array}{l}\text { Érdeklődés fokozódik } \\
\text { a felsőoktatásban, } \\
\text { tudományos képzés- } \\
\text { ben! }\end{array}$ \\
\hline $\begin{array}{l}\text { Jelentős kutatási } \\
\text { eredmények a területi } \\
\text { szerkezetről és intéz- } \\
\text { ményrendszerről! }\end{array}$ & & $\begin{array}{l}\text { Élénkülö verseny, } \\
\text { eltérő esélyekkel, } \\
\text { eltérő szakmai } \\
\text { színvonal! }\end{array}$ & $\begin{array}{l}\text { Növekvỏ befogadó } \\
\text { közeg, érdeklődés az } \\
\text { eredmények iránt! }\end{array}$ \\
\hline
\end{tabular}

Forrás: Izsák Éva közlése alapján saját átdolgozás. 
Rechnitzer János : Tükör által nem elhomályositva (A posztmodern, a paradigmák, a main stream és a csábitás ördöge a regionális tudományban.) Tér és Társadalom 19. évf. 2005/3-4. 1-12. p.

TÉT XIX. évf. 2005 - 3-4

Tükör által nem elhomályosítva ...

\section{A posztmodern, mint erösség}

A regionális tudomány új tudomány, friss szemléletü, mondjuk ki: posztmodern társadalomtudomány. A sokéves küzdelme önmagával, alkotó diszciplínáival, a szakmai versenytársakkal, a megismerés és megismertetés iránti érvényesülési vágya nyitottá, rugalmassá tette. A tér társadalomtudományi értelmezése során óhatatlanul felmerül a tudományközi jelleg. Ez értelmezésünk szerint azt jelenti, hogy meríteni kell és lehet a többi társadalommal foglalkozó tudományból, s azok formációit a konkrét vagy az elvont terekben kell érvényesíteni úgy, hogy azt egyben rendszernek, élö és változó struktúrának tekintjük.

Ha alaposan meg akarunk valamit érteni, érdemes visszanyúlni a klasszikusokhoz. Isard (1956) alapmúve a Bevezetés a regionális tudományba, - ami sajnos magyar nyelven még nem jelent meg - szemléletesen elkülöníti az alkotó diszciplínák, így a földrajz, a közgazdaságtudomány, a szociológia, a politológia, az antropológia tudományos szemléletét a regionális tudománytól. Azt mondja, általánosan, hogy mindegyiket megmeríti a térbeliségben, minden törvényszerüséget a térbeli dimenzión keresztül vizsgál, értelmez, dolgoz fel, s ebben lehet, hogy domináns a közgazdaságtan (Nemes Nagy 2003, 6), de nem az egyedüli, nem az elsődleges, talán első az egyenlök között.

Nos, tehát azáltal lesz posztmodern a regionális tudomány, hogy túllép a feltörekvő társadalomtudományokon, azokból átvesz szemléletet, módszereket, gondolkodás- és közelítési módokat, s közben kiizzadja a maga elméleteit és technikáit. A nyitottság, a sokirányú befogadás, a térnek, mint egy új, egyben sajátos társadalmi dimenziónak a vizsgálata tette újszerủvé, izgalmassá. Gondoljunk arra, hogy Krugman frissítö elméletei a közgazdaságtudományban a térbeliség átgondolásából következtek, s ennek hatására is egyre több - nemcsak külföldön, itthon is - rokon, alkotó társadalomtudományi müben megjelenik a térbeliség, mint egy sajátos, bár még nehezen kezelhetó kategória. $\mathrm{S}$ ez elismerése a regionális tudománynak, a befogadás valós tényét jelzi, a térbeliség révén feltárt összefüggések újragondolását mutatja, esetenként más szemüvegen, egy-egy alkotó diszciplína szemléletmódjában.

$\mathrm{Az}$ új társadalomtudományokra gyakran illesztik azt a jelzöt, hogy multidiszciplináris jellegúek. Ezzel intézi el a szakmai közvélemény kevésbé tájékozott része azt, hogy itt valami új megközelítés formálódik, nem a hagyományos, nem a klasszikus szemléletben történik a problémák elemzése, és a megállapításoknak számos olyan eleme van/lehet, amit ugyan megfogalmaztak már a , diszciplínák”, de más megvilágításban, más összefüggésben kerülnek értelmezésre. Példaként említhetjük a munkanélküliséget, amit a közgazdászok a gazdaság szerkezetével, annak átrendezésével magyaráznak. Míg a regionalisták azt mondják, hogy csak bizonyos terekben vannak munkanélküliségböl fakadó nehézségek, azaz nem mindenütt vannak foglalkoztatási feszuiltségek, sőt a fejlett régiókban munkaerőhiánnyal kell számolni. Továbbá a munkanélküliség feloldásánál számolni kell a lokális népesség képzettségével, szociális, kulturális értékeivel, vagy az adott gazdasági szerkezettel, annak fejlö- 
Rechnitzer János : Tükör által nem elhomályositva (A posztmodern, a paradigmák, a main stream

és a csábitás ördöge a regionális tudományban.) Tér és Társadalom 19. évf. 2005/3-4. 1-12. p.

dési irányaival, piaci kapcsolataival. A regionális elemzések azzal nyújtanak mást, újat, hogy a probléma térbeli átgondolásával a megoldásokat közelebb hozhatják, arra összpontosíthatnak, egyben árnyaltabb megoldásokat kínálhatnak.

A hazai regionális tudomány alapvető erőssége, hogy az elmúlt húsz esztendőben látványosan intézményesült. Saját kutatóintézettel, több egyetemi tanszékkel, akadémiai bizottsággal, az akadémiai doktori cím kezdeményezésével, önálló doktori iskolával (több iskolában alprogrammal), könyvsorozatokkal és folyóiratokkal rendelkezik. Az intézményesülést megerősíti, hogy létrejött a regionális kérdésekkel foglalkozó magyar szakemberek társasága ${ }^{5}$, ami egyértelmüen jelzi, hogy a társadalmi, intézményi beágyazottság megtörtént, sőt a területi kérdések egyre gyakrabban az érdeklődés középpontjába kerülnek, az azt szakmaszerüen müvelők és a tudományos kutatások együttes hatására.

Napjainkra számításaink szerint 80-120 kutató/oktató foglalkozik a regionális tudománnyal, ebben a témakörben tanít, publikál. Az akadémiai föhívatású kutatóhelyek és a szaktanszékek mellett 5-8 olyan szervezet, intézmény, vállalkozás múködik, ahol rendszeresen végeznek kutatómunkát, s azok eredményei közlésre kerülnek. A becslések 1000-1200 före teszik azok számát, akik a hazai területi intézményrendszerben regionális, területi kérdésekkel foglalkoznak, egyes sejtések szerint 15-20\%-ukhoz rendszeresen eljutnak a szakmai eredmények ${ }^{6}$.

Erősségünk tehát az, hogy rendelkezünk mủködőképes intézményrendszerrel, ennek tudományos és oktatási bázisa biztosított, de megtalálható a fogyasztói szféra is, amely igényli, sőt sürgeti a tudomány és az oktatás szakmai üzeneteit. Ezen üzenetek között nagy számban fordul elö a regionális folyamatok nemzetközi szinten elfogadott eredményeinek adaptálása, azaz a szakma tudja, mi folyik a világban, és igyekszik az ismereteket gyorsan átvenni. A magas adaptációs képesség persze inkább a regionális folyamatok alakulásában és alakításában, azok eszközeinek és intézményeinek megismertetésében jelenik meg, visszafogottabb már az új elméleti rendszerek önálló felállítása, vagy speciális területi folyamatok bemutatása, értelmezése. A rendszerváltozás és az átmenet területi sajátosságainak bemutatására koncentráló elemzéseket, illetve azokból összeállított köteteket, tanulmányokat külföldön már egyre gyakrabban forgatják, amit a hivatkozások számának emelkedésébỏl, és a szerzőkhöz eljutatott felkérések alapján állapíthatunk meg?

\section{A main stream, mint gyengeség}

Nemes Nagy Józsefnek igaza van abban, hogy a térnek, mint sajátos társadalmi kategóriának az elemzése a hazai regionál is iudományban szegényes, annak alapvetô kategóriáinak (terek, térelemek, térségi szintek, hely, helyzet, távolság, térkapcsolatok, a mozgás, térbeli fejlődés) kifejtésében, feldolgozásában, értelmezésében még igencsak visszafogott eredmények születtek ${ }^{8}$. Gyengeségünk az enciklopédikus ismereteket kínáló magyar nyelvủ művek mérsékelt száma. A nagy tömegủ szakmai könyvkiadás ${ }^{9}$ által megjelenített eredmények böséges tárházában, sajnos, nemcsak 
Rechnitzer János : Tükör által nem elhomályosítva (A posztmodern, a paradigmák, a main stream

és a csábitás ördöge a regionális tudományban.) Tér és Társadalom 19. évf. 2005/3-4. 1-12. p.

TÉT XIX. évf. 2005 - 3-4

Tükör által nem elhomályosítva ...

5

üres, sokszor unalmas emeletekre bukkanunk, hanem az esetleges bútorozást elrontja a berendezés (módszerek) eklektikus kavalkádja, azok végtelen ismétlése vagy éppen a felszínes hazai és nemzetközi adaptációk.

A regionális tudomány Magyarországon népszerü lett a kilencvenes években, a szociológia, a politológia mellett talán az egyik legfelkapottabb társadalomtudományi területnek lehetett tekinteni. Érdekes, hogy a közgazdaságtudomány, ami a múltban az egyik kedvenc volt, nem tudott népszerü lenni. Ennek oka abban keresendö, hogy a piacgazdasági modell kész volt, azt nem kellett kitalálni, csak gyorsan adaptálni, s ezt megtette maga a gazdaság. Az átvételt, az átalakulást lehetett elemezni, annak a korlátait, feltételeit, de alapvetỏ újdonságokat nem lehetett már kitalálni. Így aztán maga a tudomány sem hozta a novumokat, bár módszereiben, szemléletében, közlésében alapvetỏen megújult.

A területiség téma lett, légyen az a lokalitás, a regionalitás, azok intézményrendszerei, a regionális különbségek, az autonómiák versenye, az állam és a területi, települési közösségek viszonya, azok egymásrautaltsága. A modernizálódó társadalom felismerte, hogy a tér egy lehetséges erőforrás, az abban lévö elemek (vállalkozások, infrastruktúra, szereplök, humántényezők, tradíciók, kultúra, kapcsolatok stb.) valamiféle új energiát adhatnak. Ugyan lassan bomlott le a felülröl vezényelt társadalomszemlélet, megszünőben volt a központ, a centrum mannáinak epekedö várása. Helyette a belső erők, az együttmủködések, együttélések felé fordulás volt megfigyelhetö, bár állandóan elötörtek a régi beidegződések is.

A fö irány, a main stream a magyar regionális tudományban a területi politika intézmény- és eszközrendszerének kutatása lett. Óriási hiány volt az alulról építkező társadalom ismeretében, így nagy kereslet, komoly megrendelések születtek ennek átvételére, adaptálására.

Ki kellett találni az önkormányzatok müködésén át, a területi tervezésen keresztül egészen a regionális politika támogatási rendszerének elvéig, működéséig a területi rendszer legfontosabb alkotóelemeit. A hazai regionális tudomány ezekre a poliszi szemléletü (adaptálás, tanácsadás, irányok meghatározása, intézmények felvázolása, szemléletmód érvényesítése stb.) kutatásokra jól, sikeresen reagált.

A main streambe tartozó kutatásokkal együtt egyre több és több térbeli elemzés került felszínre, egyre mélyebben ismertük meg a magyar területi folyamatokat és szerkezeteket. Eközben a kutatások formálták a szereplők gondolkodását, alakítottak ki új tervezési, irányítási, szervezési módszereket, s világítottak rá eddig nem vizsgált problémákra. Állíthatjuk, hogy a regionális tudomány ma számos jelenségét ismeri a magyar társadalomnak, legyenek azok gazdasági, közösségi, szociális, intézményi, finanszírozási, településhálózati jellegüek (Horváth-Rechnitzer 2000; Barta-G. Fekete-Szörényiné Kukorelli-Tímár 2005). Nem hisszük, hogy a magyar regionális tudomány addig jutott volna ebben a feltárásban, hogy a „, rendszer nem müködik". Ellenkezőleg, számtalanszor elmondtuk, leírtuk, hogy a modernizáció gyorsításának melyek a legfontosabb módjai, irányai. Éppen az Európai Unió regionális politikájának feldolgozása révén jutottak el a szereplők oda, hogy tervezni kell a 
Rechnitzer János : Tükör által nem elhomályosítva (A posztmodern, a paradigmák, a main stream és a csábitás ördöge a regionális tudományban.) Tér és Társadalom 19. évf. 2005/3-4. 1-12. p.

jövőt, hogy a tervekből megvalósitási lépések sorozatát kell kidolgozni, s ehhez valamiféle belső és külsỏ területi együttmüködésre van szükség.

Egyértelmü, hogy a poliszi jellegü kutatások nem kedvelik a módszertani bravúrokat, nem az izgal mas modellekre, nem a sajátos, újszerủ becslési, mintavételi eljárásokra törekszenek, nem regionális szerkezetek alkotóinak matematikai összefüggésekbe foglalt briliáns levezetését várják el, hanem verbális leírásra, egyszerủ statisztikai táblázatokra, könnyen értelmezhetö összefüggések kimutatására, nemzetközi analógiák felvillantására szorítkoznak. Gyengesége a regionális tudománynak, hogy a main stream a bódító megrendelés mámorában nem fordított erőforrásokat a módszertani bázis folyamatos fejlesztésére, annak megalapozására. (Bár legyünk őszinték, a regionális szakmában dolgozókat kibocsátó felsőoktatási intézmények sem nyújtanak valami eget rengetỏ friss elméleti és módszertani kínálatot a hallgatói knak ${ }^{10}$, de ezt el lehet mondani, sajnos, egyes doktori iskolákról is ${ }^{11}$.)

A gyengeségek között említik fel - föleg a felsöoktatásban dolgozó kollégák -, hogy nines önálló regionális tudományi szak a magyar egyetemi képzésben. Napjainkban, még az igényesebb közgazdász- és geográfusképzésben jelenik meg markánsan vagy érzékelhetően a területtel összefüggỏ tudomány oktatása (regionális gazdaságtan, regionális politika, területfejlesztési ismeretek, területi elemzések módszerei stb. tantárgyakban, vagy azok együttesét jelentö szakirányokban).

Vannak kezdeményezések föiskolai, sỏt egyetemi szinten a területfejlesztés, vidékfejlesztés szakembereinek képzésére, de ezeknél a kísérleteknél egy-egy korábbi - föleg agrár - képzési irányok átmentése, továbbéltetése regisztrálható csupán.

Legyen-e önálló képzési terület a regionális tudomány? Vagy egy-egy alapdiszciplínán belül szakirányokban jelenjenek meg a területi ismeretek, illetve a posztgraduális továbbképzésekben tudjanak az igénylők ismereteket szerezni a regionális folyamatok elemzéséről, azok tervezéséről, szervezéséröl, irányításáról?

Ezek a kérdések hosszú idó óta foglalkoztatták a szakmát (Lengyel 1998; Korompai 1998; Buday-Sántha 2000), s végül egységes állásfoglalásként megfogalmazódott, hogy a kétszintü felsőfokú képzésben ơnálló alapszakként (BA) nem célszerủ regionális tudományhoz kötődő képzést kezdeményezni a gazdaságtudományi területen belül. Ismerve a magyar felsőoktatás viszonyait, amit egy szakterület kiérlel és szakmailag megalapozottan elhatároz, az más tudományterületeken az érdekek áldatlan harca következtében - már nem érvényes, nem érvényesíthetô. Így született meg az agrártudományban a gazdaság- és vidékfejlesztési mérnök, mint alapszak (BA), ahol több regionális tudományi tárgy jelent meg az alapozó szaktárgyak között, illetve területi szakirányok szerveződtek.

A mesterképzésben (MA) szükségesnek és igencsak kívánatosnak tartjuk, hogy legyen regionális tudományi szak, döntően és meghatározóan a gazdaságtudományokon belül. Információk szerint a földtudományok és a fentebb jelzett agrártudományok mesterképzésében is tervezik hasonló szakok alapítását. Bízunk abban, hogy a minősítő szervezetek figyelembe veszik azokat az állásfoglalásokat, amiket a regionális tudomány szakmai szervezetei ebben a kérdésben hoztak ${ }^{12}$. 
Rechnitzer János : Tükör által nem elhomályosítva (A posztmodern, a paradigmák, a main stream és a csábitás ördöge a regionális tudományban.) Tér és Társadalom 19. évf. 2005/3-4. 1-12. p.

TÉT XIX. évf. 2005 - 3-4

Tükör által nem elhomályosítva ...

A gazdaságtudományokon belül célszerủ egy regionális és környezettudományi mesterképzést (MA) alapítani, de más, további mesterképzésekben is kívánatos a regionális tudomány legfontosabb alkotóelemeinek a beépítése, gondolunk itt a regionális gazdaságtan, a regionális politika és a területi tervezés, elemzés, program eljárásainak megismertetésére. Az önálló regionális és környezettudományi mesterképzésen (MA) belül már szakirányokban lehet a legfontosabb szakmai irányokra a figyelmet irányítani, így a térségi gazdaságfejlesztésre, a vidékfejlesztésre, a területi tervezés és programozás eszközrendszereire, a településfejlesztés, üzemeltetés, gazdálkodás irányaira.

Látni kell, hogy a hazai felsőoktatásban egyre erösebb - és mondhatni kíméletlenebb - verseny bontakozott ki. Szakmai ismereteink alapján a mesterképzés feltételei 3-4 egyetemen adottak, ahol számottevőek hazai, nemzetközi vonatkozásban a kutatási kapacitások, s ezeket kidolgozó szakemberek koncentrálódtak. Ennek hiányában a szakszerü mesterképzést különféle trükkökkel be lehet indítani, azonban a piaci megmérettetésben ezek az intézmények gyorsan le fognak maradni. 2008-tól itt a nagy alkalom, hogy a magyar regionális tudomány ne csak néhány tantárggyal, hanem egy igényes mesterszakkal tevőleges alakítója legyen a felsőoktatásnak. Hisszük azt, hogy a tudományterület eredményei és az azokat megvalósító kutatóhelyek bázisán európai rangú, ismert és elismert regionális tudományi mesterképzés eredményeiröl adhatunk számot a 2010-es évek közepén.

\section{Paradigmaváltás helyett korrekció, mint lehetöség}

Nemes Nagy József dolgozatában két alapvető irányzatot különböztet meg a magyar regionális tudományban (Nemes Nagy 2003). Az egyik, nevezzük térelméleti iskolának, amely az alapvetö térbeli társadalmi egyenlőtlenségeket vizsgálja, annak dimenzióit elemzi a térelemek különféle megjelenési formáiban és ezzel a térszerkezet összetételét, mozgásait kísérli meg leírni, esetleg modellezni. A másik, nevezzük regionális társadalom- és intézményelméleti iskolának, a területi fejlődés mozgatóit kutatja. Elemzéseinek középpontjában a régiók és a kistérségek intézményrendszerei állnak. Egy kívánt jövőbeli állami modell, a decentralizáció szemüvegén keresztül értékeli a rendszer müködését, s nemzetközi analógiák, hazai sajátosságok alapján javaslatokat ajánl egy nyitottabb, alulról építkező berendezkedésre.

Ưdvös és ígéretes, hogy nálunk, Magyarországon ez a két regionális tudományi iskola müködik, azok között a kapcsolat élö és termékeny, nem ellentétes és versengỏ. Nincsenek konfliktusok, egymás eredményeit felhasználják, hiszen míg az egyik a módszertanban erős és ezzel a regionális folyamatok belső összefüggéseinek mélységeihez vezet el, addig a másik alaposabb empirikus bázissal rendelkezik, a fejlödés és a fejlesztés logikáit rendszerezi, megoldási módokat, recepteket tud adni a döntéshozóknak és a szereplöknek a beavatkozás mikéntjeire. Egymásra épülés, a kooperáció, a folyamatos kommunikáció tehát a szakmában jelen van. 
Rechnitzer János : Tükör által nem elhomályositva (A posztmodern, a paradigmák, a main stream és a csábitás ördöge a regionális tudományban.) Tér és Társadalom 19. évf. 2005/3-4. 1-12. p.

Nem hisszük tehát, hogy az elkövetkezö 5-8 évben alapvetö paradigmaváltásra lenne szükség a magyar regionális tudományban. Viszont korrekciók szükségesek, ezeket részben a tudomány önfejlödése, részben a piac motiválja. Eddig bájosan elkerültük a regionális tudomány piacát, elegánsan elhallgattuk, holott - legyünk öszinték - abból élünk, abból tudjuk az intézményeinket sikeresen müködtetni, a szakembereket megtartani, valamiféle szakmai karriert kínálni a versenyszférával szemben. Szóval ne legyünk álszentek, finomkodók, igenis fontos, meghatározó a regionális tudomány piacának alakulása, a felmérhetô és alakítható igények rendszerezése, beépítése a jövőképbe.

Mit kíván a piac? Egyértelmű, hogy teret nyer a decentralizáció, a szereplők nagyobb mozgásszabadságot kapnak (lásd Európai Unió), így aztán alaposabb szerkezeti elemzésekre, mélyebb belső vizsgálatokra lesz szükség. Le kell írni a jövőt, fejlődési pályákat, perspektívákat, lehetséges szcenáriókat, megoldási módokat kell felvázolni, s ehhez a területrendszer alaposabb szerkezeti összefüggéseit, külső kapcsolati hálózatát célszerủ analizálni. Nem lesz elég a terveket, a programokat, az intézményeket megadni, már kellenek a hogyanok, a hatások és következmények, amikhez alaposabb leírás, sỏt - uram bocsáss - modellek felállítása, sỏt azok mủködtetése igényeltetik.

Mit kíván a regionális tudomány? A mi olvasatunkban a regionális tudomány hiánypótlást kivván. Ez a hiánypótlás az eddigi kutatások alapján az elméleti rendszerek szakszerủbb összefoglalása, azok közérthetö közreadása, a „monográfiák mellett kézikönyvek" program beindítása. Igényes szakmai kézikönyvek szükségesek, amikben végre rendszerezzük a felhalmozott ismereteket, fontos, hogy ezek ne csupán adaptációját jelentsék a nevesebb külföldi klasszikus munkáknak, hanem a mi viszonyaink, a mi folyamataink alapján a regionális tudomány törvényszerüségeinek új értelmezéseit, feldolgozásait jelenítsék meg. Tapasztalható a nemzetközi fórumokon, hogy már más az érdeklödés, mint a csodaváró rendszerváltozás idején. A múlt bemutatása, leírása helyett az elmozdulások, az európai rendszerekhez való igazodás és bekapcsolódás az izgalmas, a nyafogó és fanyalgó átmenet-analízis helyett a megújítási irányok és az integrációs törekvések mondhatnak újat, mást.

A regionális tudomány az országot nem szemlélheti szigetként. Európában nagyrégiók szerveződnek, ezek országokat, azok nagytérségeit fogják át, hasonló vagy azonos térfolyamatok alapján. Egyértelmú, hogy a Kárpát-medence ${ }^{13}$, illetve Közép-Európa egészének területi szerkezete kínálhat új kutatási lehetőségeket, amihez döntóen ebben a nagyrégióban található kutatóhelyeknek, egyetemi bázisoknak az összefogására, szakmai együttmüködésére van szükség. Szerepünk lehet abban, hogy résztvevői, esetleg egyes témákban szervezői lehetünk a közép-európai regionális tudományi kutatási programnak, s ezzel új dimenziókat nyitunk meg a hazai szakma számára is.

Miközben már érzékelhetö a transznacionális dimenziók felé történő kacsingatás, emellett növekszik a hazai érdeklödés a tudományterület iránt. Érvényes ez a fentebb jelzett felsőoktatásra, vagy éppen a müködỏ doktori programra, de nem el- 
Rechnitzer János : Tükör által nem elhomályositva (A posztmodern, a paradigmák, a main stream

és a csábitás ördöge a regionális tudományban.) Tér és Társadalom 19. évf. 2005/3-4. 1-12. p.

TÉT XIX. évf. 2005 - 3-4

Tükör által nem elhomályosítva ...

9

hanyagolható a szakmai tömegbázis érzékelhetỏ szélesedése sem² ${ }^{14}$ A társadalom igénye a regionális tudomány eredményei iránt akkor lesz töretlen, ha egyik oldalról minél alaposabban és érthetően tudjuk bemutatni a magyar és közép-európai térszerkezet sajátosságait, a másik oldalról viszont képesek vagyunk az államreform területi dimenzióihoz intézményi megoldásokat kidolgozni.

Összeér tehát a fejezet bevezetőjében jelzett két iskola, egymás nélkül nem megy. A lehetőségeket csak a kölcsönhatások érvényesítésével, s ennek következtében az alaposabb összefonódással tudjuk elérni, aminek viszont nélkülözhetetlen feltétele a folyamatos szakmai beszélgetés, vita, egymás munkájának értékelése, netalántán elismerése.

\section{A csábitás ördöge, mint veszély}

A regionális tudomány számos veszélynek van kitéve. Az első, mint minden társadalomtudománynál, a politika csábítása. Most, hogy végre elkezdődik valami a regionalizáció ügyében, nagy kihívás elött áll a szakma.

Meddig és hogyan legyünk következetesek, meddig lehet tartani a kemény tények szorítását, vagy hol a kutató, oktató felelössége a politikai döntésekben? Hol és milyen formában mondjuk el a véleményünket, a „nem lehet, nem szabad'" mögött húzódó keserủ igazságokat? Azt hisszük, ezt minden kutatónak, oktatónak és azok intézményeinek önmagának kell eldönteni.

A politika gyorsan akar lépni, így aztán olyan igényekkel jelentkezik ebben a kritikus időben, ami gyorsított rapidelemzéseket tesz szükségessé. Mindez felületességet teremt, expressz kutatásokat indít meg, persze sok esetben ezek mögött már alapos elemzések állnak, csak a döntéshozók nem ismerik az irodalmat, vagy nem érnek rá az általuk megrendelt kutatásokat elolvasni, illetve azok nem érhetők el a szakmai nyilvánosság számára.

Sajnos, vagy reménykeltő (?), hogy újabb és újabb regionális „eszkimók” jelennek meg, akik változatlanul nagy és jó üzletet látnak a regionalitásban, annak az európai uniós csatlakozás motiválta hatásaiban. Többségében csillogó név alatt, időnként megzsírozott kapcsolatokkal látványosan nyomulnak sokszor a tudatlanság teljes biztonságával. Mindennek alapvetően örülni kell, hiszen mi teremtjük a jövőt, mi ösztönözzük a szakmai bázis szélesítését, akkor nem leszólni kell az új szereplöket, hanem ringbe szállni velük. A verseny a jövöben igencsak élénkül, s a szereplök nemcsak itthonról, hanem külföldről is készülödnek, vagy már rendezik be irodáikat. Más és más helyzetben vannak azok, akik a piaci szférában ténykednek, és eltérỏ a lehetősége az akadémiai vonalon működő szervezeteknek, kutatóknak, oktatóknak. Nem az elegáns elzárkózás a kívánatos, meg kell találni az okos kompromisszumokat a szakmai igényesség elfogadtatható mezsgyéjén.

Sokszor merül fel bennünk, hogy meddig kutatás egy probléma és mitöl tanácsadás. Nemes Nagy cikkében is felmerül az alkalmazott kutatások stigmája. Valahogy nálunk ez egy negatív megítélés, nem elég elegáns, nem elég fennkölt, mondhatni nem elég tudományos. Ki kell mondani, a nálunk mủvelt regionális tudomány 
Rechnitzer János : Tükör által nem elhomályosítva (A posztmodern, a paradigmák, a main stream és a csábitás ördöge a regionális tudományban.) Tér és Társadalom 19. évf. 2005/3-4. 1-12. p.

még többségében alkalmazott, gyakorlatorientált tudomány, amely a térben jelentkezō. vagy az azáltal generált problémákat tárja fel, azok változtatására kívån megoldásokat adni. Ezen válaszokat lehet felhasználni fejlesztési döntéseknél, vagy éppen jelenthetik azok kereteit, feltételeit, értelmezési tartományait. De figyelmen kívül is lehet hagyni - amit tesznek a politikai és gazdasági döntéshozók -, mint minden társadalomtudományi üzenetet. Nem az a lényeg, hogy használják vagy nem, hanem az, hogy a problémát szakmailag alaposan, módszertanában igényesen, a tudományos szintézis gondosságával dolgozzuk fel, s az eredményekkel hozzájáruljunk a jelenségsorozat megértéséhez. Ha így teszünk, akkor hasznosat teszünk, és elfeledhetjük az alkalmazott és elméleti tudomány látszatvitáját.

Minden gyakorlati elemzés mögött meg lehet találni azt az elméleti és módszertani bázist, aminek kidolgozása, pontosítása vagy éppen tesztelése új eredményeket adhat. Nem mi fújjuk a passzátszelet! Nem nálunk fognak a regionális tudomány új, világot rengetö felfedezései megszületni! Ám az igényes, gondos elemzések, megalapozott, kiérlelt vizsgálatok igenis nyújtanak egy-egy részkérdésben új összefüggéseket. A veszélyt abban látjuk, hogy még jellemző a befelé fordulás, a saját, itthoni közösségeinkben való - sokszor már unalmas - önismételgetés, holott nincs magyar regionális tudomány, hanem regionális tudomány van, így az eredményeinket a nemzetközi porondokon mérik, és mérhetjük meg.

\section{Hogyan tovább regionális tudomány?}

Qui vadis? A szerző - s egyben az optimisták - kedvenc kérdése! 1988-ban alakult meg az MTA Regionális Tudományos Bizottsága, a tizennyolc esztendő igazolta a döntés helyességét és értékállóságát. Létrejött egy új társadalomtudományi szakterület, annak minden kellékével, eredményével és problémájával együtt. Jelen van, és dinamikusan fejlódik Magyarországon a regionális tudomány. Rajtunk múlik, hogy elfogadottsága itthon és külföldön miként alakul.

A tükörben látható kép nem homályos, hanem tiszta és bizakodást sugároz!

\section{Jegyzetek}

${ }^{1}$ A jelen Tér és Társadalom számban az RTB hírei között olvashatjuk a Bizottság 2003-2005. évi tevékenységének értékelését.

${ }^{2}$ Áltekintettuk a vezetö szakmai folyóirat elmúlt tíz éves számait és csak három cikkre bukkantunk, ami a regionális tudomány értékelésére, küldetésének megfogalmazására vonatkozotı (Rechnitzer 1996, 2000; Nemes Nagy 2003).

${ }^{3}$ A legutóbbi élményeink ezzel kapcsolatban Enyedi György professzor úr 70. születésnapját köszöntỏ tudományos uulésen (2005. május) elhangzott hozzászólások, és a MTA Regionális Tudományos Bizottságának fentebb jelzett újjáalakuló taggyúlésén elhangzott felszólalások (2005. október 26.).

${ }^{4}$ Izsák Éva nem publikálta a regionális tudomány elsô SWOT-elemzését, így engedélyt kértủnk a szerzötöl, hogy módszerét felhasználhassuk, kiegészítve az általa közölteket saját tappasztalainkkal.

${ }^{5}$ Magyar Regionális Tudományi Társaság; www.mrtt.hu

${ }^{6}$ Szoboszlai Zsolt: A térségi kutatások hatékonysága. Kézirat, Szolnok. 2003. 
Rechnitzer János : Tükör által nem elhomályosítva (A posztmodern, a paradigmák, a main stream és a csábitás ördöge a regionális tudományban.) Tér és Társadalom 19. évf. 2005/3-4. 1-12. p.

TÉT XIX. évf. 2005 @ 3-4 Tükör által nem elhomályosítva ... 11

${ }^{7}$ Az MTA RKK Discussion Papers sorozat minden fontosabb nemzetközi szakmai fórumra eljut, s annak köteteire történő hivatkozások száma látványosan emelkedik. Két jelentôs tanulmánykötet szủletett az átmenet regionális folyamatainak bemutatására, az egyik magyar (Horváth-Rechnitzer 2000), a másik az elmúlt évben jelent meg angol nyelven (Barta-G. Fekete-Szörényiné Kukorelli-Tímár 2005).

8 A nevezett által szerkesztett regionális elemzési módszertani kézikönyv (Nemes Nagy 2005) hatását még nem lehet megállapítani, de döntỏen befolyásolja az alapfogalmak és az alapozó módszertan egységes értelmezését és használatát.

${ }^{9}$ A MRTT honlapján (www.mrtt.hu) megtalálható a regionális tudományhoz kapcsolódó szakkönyvek listája 2005. évre. Ez alapos felsorolása a szakma adott évi irodalmának, s ennek alapján megállapíthato, hogy közel 50 kötet jelent meg. Ezek között viszont átfogó, rendszerezó, alapozó monográfiákat csak kis számban találunk.

10 Magunkat szidjuk elsöként, hiszen hosszú éveket kellett várni egy alapos regionális gazdaságtan tankönyv kidolgozására, de végre elkészült (Lengyel-Rechnitzer 2004). Ugyanakkor várat magára k:y átfogó alapmú a regionális politika tanulmányozására. Most, 2005-ben jelent meg a módszertani h. könyv (Nemes Nagy 2005), de számos további elméleti alapozó munka magyar nyelven nem olvashatio.

II Az egyik doktori iskola által kiadott évkönyvben egyetlen matematikai képletet nem találtunk, de honnan is vennének a doktoranduszok friss módszertani ismereteket, ha a Tér és Társadalom címü szakmai folyóiratban (önkritika egyben) elvétve bukkan fel egy egzakt levezetés, egy modell szemléletủ feldolgozás, vagy új módszer a klasszikus lerágott csontokon (faktor- és klaszterelemzés) túl,

${ }^{12}$ Állásfoglalás a regionális tudományt érintő kétszintü képzésről, MTA Regionális Tudományos Bizottsága, 2004. november.

13 Jó példája ennek a Kárpát-medence régióit bemutató kötetsorozat indítása (Horváth 2003, 2004), vagy a CADSES program által is támogatott kutatási együttmüködések beindulása,

14 Mindezt a konferenciákon való részvételben, valamint a kiadványok terjesztésében lehet jól lemérni, de a doktori programokra való jelentkezés tartós emelkedése is jelzi a szakma iránti „tu dáskeresletet”.

\section{Irodalom}

Barta, Gy.-G. Fekete, É--Szörényiné Kukorelli, I.-Tímár, J. (eds.) (2005) Hungarian Spaces and Places Patterns of Transition. Centre for Regional Studies, Pécs.

Buday-Sántha A. (2000) A Regionális Felsőoktatás c. konferencia föbb megállapításai és javaslatai. Tér és Társadalom. 4. 165-166, o.

Horváth Gy. (szerk.) (2003) Székelyföld. (A Kárpát-medence régiói 1.) MTA RKK, Dialóg Campus Kiadó, Budapest-Pécs.

Horváth Gy. (szerk,) (2004) Dél-Szlovákia. (A Kárpát-medence régiói 2.) MTA RKK, Dialóg Campus Kiadó, Budapest-Pécs.

Horváth Gy.--Rechnitzer J. (szerk.) (2000) Magyarország terilleti szerkezete és folyamatai az ezredfordulón. MTA RKK, Pécs.

Korompai A. (1998) A területi szakképzés irányai - az együttmüködés lehetôségei. - Tér és Társadalom. 4. 143-160. o.

Lengyel I. (1998) Regionális ismeretek oktatása a magyar felsöoktatásban. - Tér és Társadalom. 1-2. 171-175. o.

Lengyel I.-Rechnitzer J. (2004) Regionális gazdaságtan. Dialóg Campus Kiadó, Budapest-Pécs,

Nemes Nagy J. (2003) A regionális tudomány dualitása és paradigmái - hazai tükör. - Tér és Társadalom. 1. 1-17. 0 .

Nemes Nagy J. (szerk.) (2005) Regionális elemzési módszerek. (Regionális Tudományi Tanulmányok 11. kötet) ELTE Regionális Földrajzi Tanszék, MTA-ELTE Regionális Tudományi Kutatócsoport, Budapest.

Rechnitzer J. (1996) A regionális tudomány helyzete, - Tér és Társadalom. 2-3. 1-12. o.

Rechnitzer J. (2000) A regionális tudomány és intézményrendszere. - Tér és Társadalom. 2-3. 3-8. o. 
Rechnitzer János : Tükör által nem elhomályosítva (A posztmodern, a paradigmák, a main stream és a csábitás ördöge a regionális tudományban.) Tér és Társadalom 19. évf. 2005/3-4. 1-12. p.

12 Rechnitzer János TÉT XIX. évf. 2005

$3-4$

\title{
NOT BEING BLURED BY A MIRROR (THE POST-MODERN, THE PARADIGM, THE MAIN STREAM AND THE EVIL OF TEMPTATION IN THE SCIENCE OF REGIONALISM)
}

\author{
JÁNOS RECHNITZER
}

This study reviews the status of regional science in Hungary. Retraces the strenghts, weaknesses, opportunities and possibilities of this new, dinamicly developping social science by the help the SWOT analyze. The author states that regional science is institutionalized in Hungary and every condition and requirement is given. It's social reception and effect is getting more and more important; the interest on the results and adaptation is increasing.

This big amount of analysis just had given the processing of the regional processes and institutions of the Hungarian transition; had not created overall theoretical establishments. The base literature of this science building on Hungary's researches is limited but moving by degrees is observable. Several parts of regional science were educated just by so called parteducation for years; there is a hope that the education starts on master level by the two-tier training system. The possibilities of this field of science are widening, since the conditions of scientific cooperation are being created in the Carpathian basis and in Central - Europe. The interest about the regional analysis is going to rise. Risks have to be taken into consideration, while researches are hold up to politics; it is frequently a dilemma to divide guidance and research; but we have to mention that more and more competitors appear on the market of society analysis and development. Regional science had got strong position in Hungary; the most important is to test them on international level and to present them. 